\title{
Fossil wood of Duabanga from the Siwaliks of Sindhuli area, eastern Nepal
}

\author{
M. Prasad ${ }^{1}$, U.M.S. Pradhan ${ }^{2}$ and Shyam KC ${ }^{2}$ \\ ${ }^{\prime}$ Birbal Sahni Institute of Palaeobotany, \\ 53 University Road, Lucknow - 226 007, India \\ ${ }^{2}$ Petroleum Exploration Promotion Project, \\ Department of Mines and Geology, Kathmandu, Nepal
}

\begin{abstract}
A fossil wood belonging to the extant genus Duabanga Buch-Ham of Sonneratiaceae has been represented the collection from the Siwaliks of the Sindhuli district, eastern Nepal. As the modern equivalents of the fossil wood grow now in the Indo-Malayan region, its presence in the Siwaliks of Nepal is phytogeographically important and indicates more humid climate at the time of deposition.
\end{abstract}

\section{INTRODUCTION}

The Siwalik rocks are exposed all along the Himalayan foot hills from western Pakistan in the west to Assam, India in the east covering a length of $2400 \mathrm{~km}$ with $20-25 \mathrm{~km}$ width. It lies between the Main Boundary Thrust (MBT) and the Gangetic Plain and consists of Miocene to lower Pleistocene molasse sediments deposited in the foreland basins of the Himalaya (Gansser, 1964; West and Munthe, 1981; Tokuoka et al., 1986). Throughout Nepal the Siwaliks can be divided into three lithostratigraphic units - Lower Siwaliks, Middle Siwaliks and Upper Siwaliks (West and Munthe, 1981; Herail et al., 1986; Delcaillau et al., 1987). The Middle Siwaliks are further subdivided into Lower (MS1) and Upper (MS2) units ( DMG, 1987). Their contact is placed at the base of sandstone having extraformational clasts of scattered pebbles. The present fossil locality is in the Upper Middle Siwaliks (MS2) exposed at Gauri Khola, a tributary of the Kamala River in eastern Nepal (Fig. 1). The fossil wood was found in the thickly bedded, arkosic sandstone.

\section{MATERIAL AND METHOD}

The fossil wood was collected in situ from the Gauri Khola, eastern Nepal. In the outcrop, it was a single piece of petrified wood, dark brown in colour and $70 \mathrm{~cm} \times 15 \mathrm{~cm}$ in size. The sample broke into several pieces when dug out. The specimens are semisilicified. They were sliced into thin pieces in different planes (i.e. transverse, tangential and radial). Thin sections were studied under the microscope.

\section{SYSTEMATIC DESCRIPTIONS}

\author{
Family SONNERATIACEAE \\ Genus DUABANGA Buch-Ham \\ Duabangoxylon indicum [(Navale) Awasthi] Awasthi \\ and Prasad, 1987, Fig. 2 (a-e)
}

Duabangoxylon tertiarum Prakash and Awasthi, 1970, p. 38, Pl. 5, Fig. 24, 26, 27; Pl. 6, Fig. 31.

Duabangoxylon tertiarum (Prakash and Awasthi) Kramer, 1974, p. 153, Pl. 32, Fig. 148-151, 153-157. Duabangoxylon indicum (Navale) Awasthi, 1981, p. 161-165; Pl. 1, Fig. 1, 3, 5.

Duabangoxylon indicum [(Navale) Awasthi] Awasthi and Prasad, 1987, p. 292-294, Pl. 1 Fig. 1, 3, 5.

Description

Wood diffuse porous.

Growth rings indistinct due to poor preservation, Vessels small to medium size, t.d. $56-120 \mu \mathrm{m}$, r.d. $60-200 \mu \mathrm{m}$, solitary and in radial multiples of $2-4$, almost evenly distributed, circular to oval in shape 


\section{Prasad et al.}

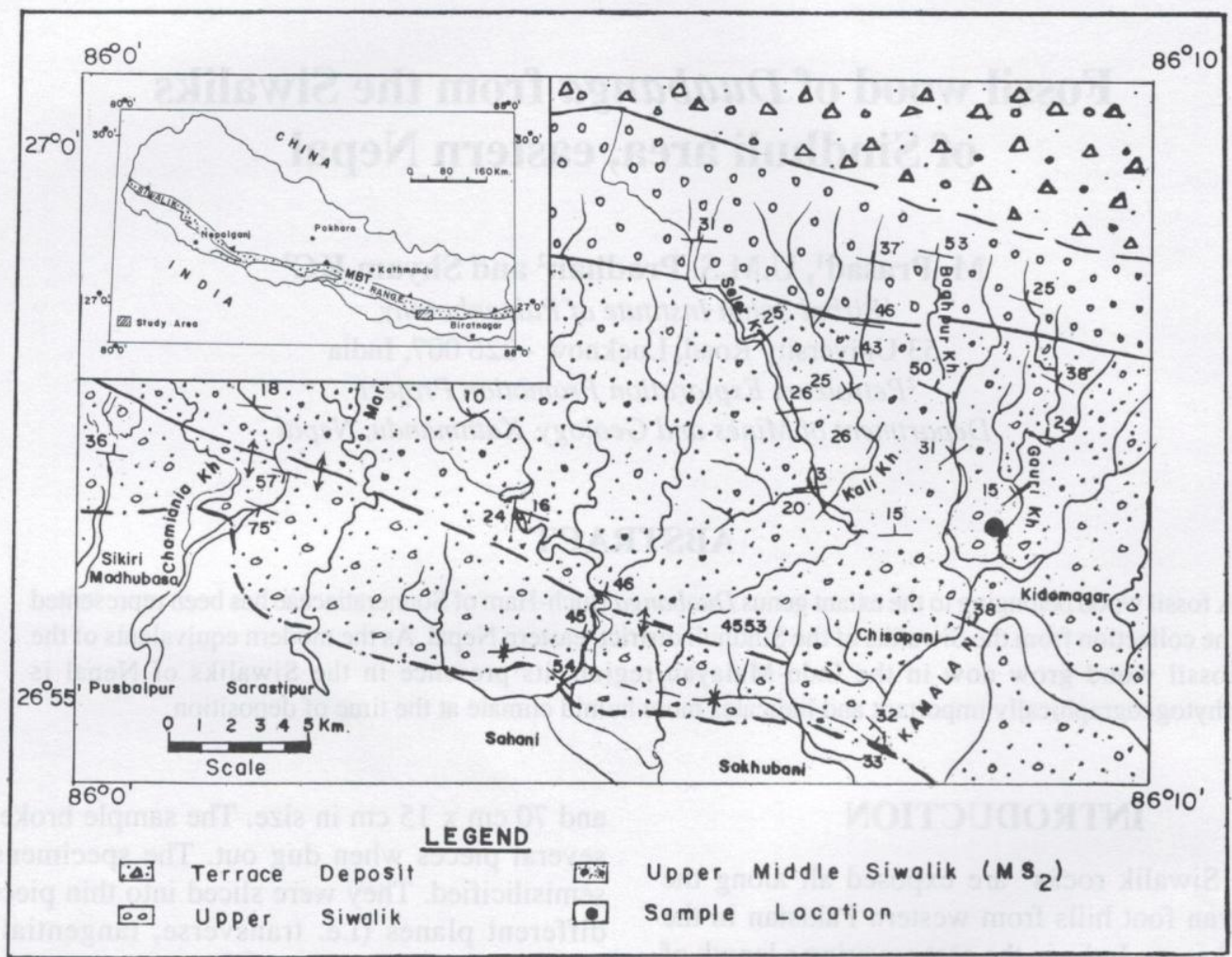

Fig. 1: Geological map of a part of Dhanusha and Sindhuli districts, eastern Nepal.

(12-20 per sq. mm); profusely tylosed (Fig. 2a,b), vessel members are $160-560 \mu \mathrm{m}$ in length, usually with truncate ends, perforations simple; intervessel pits vestured, alternate, 8 to $12 \mu \mathrm{m}$ in diameter, and orbicular to oval in shape with linear to lenticular apertures (Fig. 2c).

Parenchyma scanty paratracheal to vasicentric forming 1-2 seriate, complete to incomplete sheath around vessels, occasionally extending sideway, thin walled, round to oval, $16-20 \mu \mathrm{m}$ in diameter (Fig. 2e), $70-150 \mu \mathrm{m}$ in length.

Xylem rays fine, 1-2 seriate, (mostly 1), 3-35 $\mu \mathrm{m}$ in height, $16-36 \mu \mathrm{m}$ in width, $140-320 \mu \mathrm{m}$ in length, 12-16 rays per $\mathrm{mm}$ (Fig. $2 \mathrm{c}$ ), ray tissues heterogeneous, rays homocellular to heterocellular, heterocellular rays consisting 1-2 marginal rows of upright or square cells at one or both the ends and rest procumbent cells; upright or square cells $25-40$ $\mu \mathrm{m}$ vertical height and $18-22 \mu \mathrm{m}$ radial length, procumbent cells $20-45 \mu \mathrm{m}$ in vertical height and
30-60 $\mu \mathrm{m}$ radial length (Fig. 2d).

Fibres oval to angular in cross section, $15-35 \mu \mathrm{m}$ in diameter, moderately thick-walled, nonseptate, 560 $850 \mu \mathrm{m}$ in length, pits not seen.

\section{Affinities}

The characteristic features of the present fossil wood are small to medium-sized vessels with abundant tyloses, scanty to vasicentric paratracheal parenchyma, 1-2 heterogeneous xylem rays and nonseptate fibres. They indicate the affinity with the woods of extant genus Duabanga of the family Sonneratiaceae (Pearson and Brown, 1932; Metcalf and Chalk 1950; Пlic, 1991).

In order to determine its specific similarity wood slides of available species of Duabanga and published literature were consulted. This exercise revealed that the present fossil has close resemblance with modern D. grandiflora (Roxb. DC) Walp (Syn . 
Fossil wood of Duabanga from the Siwaliks of Sindhuli area, eastern Nepal
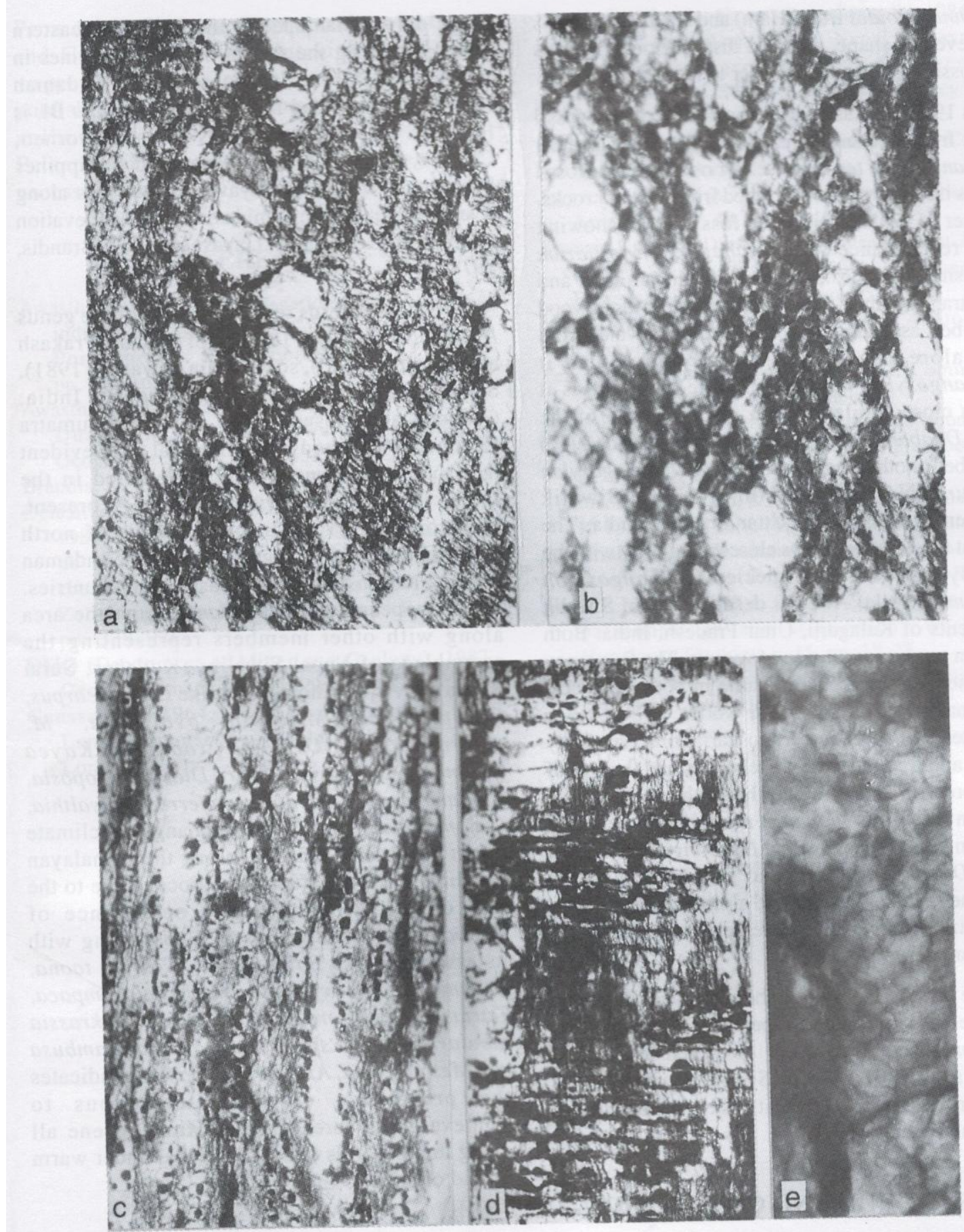

Fig. 2: Duabangoxylon indicum [(Navale) Awasthi] Awasthi and Prasad: (a) cross-section in low power showing the nature and distribution of vessels. $x 45$, (b) cross-section in high power showing multiples tylosed vessels and paratracheal parenchyma. $x$ 70, (c) tangential longitudinal section showing nature of xylem rays. $x$ 70, (d) radial longitudinal section showing heterogenous xylem rays, (e) magnified intervessel pit-pairs. $x 425$. 
D. sonneratioides Buch-Ham) and D. maluccana Bl. However, in shape, size and distribution of vessels the fossil wood is more closer to D. maluccana $\mathrm{Bl}$.

In 1970, Prakash and Awasthi described a fossil wood from Tertiary of eastern India and named it Duabangoxylon tertiarum. Later on three more fossil woods have also been described from Tertiary rocks. Kramer (1974) described a fossil wood showing close resemblance with Duabagoxylon tertiarum Prakash and Awasthi from Neogene of Java and Sumatra. Awasthi (1981) reinvestigated a fossil wood described as Sapindoxylon indicum (Navale) from Cuddalore series, south India and named it Duabangoxylon indicum (Navale) Awasthi as it shows close similarity with modern wood of the genus Duabanga. Lastly, Awasthi and Prasad (1987) described another fossil wood under Duabangoxylon indicum (Navale) Awasthi from the Siwalik sediments of Kalagarh, Uttar Pradesh, India. The present fossil wood shows closest similarity with the already known fossil species Duabangoxylon indicum (Navale) Awasthi described from Siwalik sediments of Kalagarh, Uttar Pradesh, India. Both of them possess same size of vessels. The frequency of vessels and rays is also same in both. A critical examination of known fossil woods of Duabanga indicates that there is certain variations especially in size and frequency of vessels, rays and the size of the fibres. In order to see these variations in the modern woods of Duabanga a number of section of different wood specimens of Duabanga grandiflora (Syn. D. sonneratioides) and D. maluccana were examined critically and found almost same variation in the size and frequency of vessel, frequency of rays and diameter of fibres.

The present fossil wood shows close affinity with the already known fossil species, Duabangoxylon indicum [(Navale) Awasthi] described by Awasthi and Prasad (1987) from Siwalik sediments of Kalagarh, India. Therefore, it has been identified as the same species.

\section{DISCUSSION AND CONCLUSION}

The genus Duabanga Buch-Ham. consists of three species distributed in the Indo-Malayan region (Willis, 1973). Out of them, D. grandiflora (Roxb. ex DC) Walp. (Syn. D. sonneratioides Buch-Ham.) is the only Indian species that grows in eastern Himalaya, along the stream banks and ravines in Assam and Burma. It also occurs in Andaman Islands, Thailand and Malaya. D maluccana $\mathrm{Bl}$. is found in the primary forests of Java, Borneo, Celebes, Malucca, New Guinea and Philippines Islands and D. taylorii Jayaveera flourishes along river banks in the moist mid country at an elevation of $457 \mathrm{~m}$ above sea level (Jayaveera 1967; Brandis, 1971).

From the records of fossil woods of the genus Duabanga from the Tertiary of Assam (Prakash and Awasthi, 1970), south India (Awasthi, 1981), Siwaliks of Kalagarh, Uttar Pradesh, India, (Awasthi and Prasad, 1987), Java and Sumatra (Kramer, 1974) and eastern Nepal it is evident that this genus was widely distributed in the Indian subcontinent during Neogene. At present, it is confined to the tropical forests of north eastern India (West Bengal and Assam), Andaman Islands, and in some north east Asian countries. The disappearance of Duabanga from the area along with other members representing the assemblage of Nepal Siwaliks (Koilabas, Surai Khola and Arjun Khola, etc.), like Dipterocarpus, Calophyllum, Millettia ovalifolia, $M$. macrostachya, Ormosia robusta, Kayea floribunda, Ryparosa kunstlri, Diospyros toposia, Cinnamomum inuctum, Mesua ferrea, Polyalthia, Cynometra etc. indicates that changes in climate might have taken place all along the Himalayan foot hills of Nepal after Mio-Pliocene due to the rise of the Himalaya. The occurrence of Duabanga in the Siwaliks of Nepal along with its associates like Bauhinia sp., Cedrela toona, Eugenia sp., Dysoxylum sp., Michelia champaca, Tetrameles nudiflora, Terminalia sp., Chukrassia tabularis, Albizia sp., Dillenia indica, Bambusa sp., Mesua ferrea, Artocarpus chaplasa indicates the prevalence of moist deciduous to semievergreen forest during Mio-Pliocene all along the foot hills of eastern Nepal under warm humid climate.

\section{ACKNOWLEDGMENTS}

The authors are grateful to Dr. R.P. Bashyal, Project Chief, Petroleum Exploration 
Fossil wood of Duabanga from the Siwaliks of Sindhuli area, eastern Nepal

Promotion Project, Department of Mines and Geology, Nepal for his kind permission to provide the samples for identification and to publish this article. The thanks are also due to authorities of Birbal Sahni Institute of Palaeobotany, Lucknow, India for providing necessary facilities.

\section{REFERENCES}

Awasthi, N., 1981, Reinvestigation of Sapindoxylon indicum Navale from the Cuddalore Series near Pondicherry. Palaeobotanist, v. 27(2), pp. 161-165.

Awasthi, N. and Prasad, M., 1987, Occurrence of Duabanga in the Siwalik sediments. Geophytology, v. 17(2), pp. 292-294.

Brandis, D. 1971, Indian trees. Dehra Dun, India.

Delcaillau, B., Herail, T., Mascle, T. and Mascle, G., 1987, Evolution geomorphostructurale de fronts de chevauchements a actifs: le cas des chevauchements intrasiwalika du Nepal central. Zeitschrift fur Geomorphogie N.F., v. 31, pp. 339-360.

DMG (Department of Mines and Geology), 1987, Geological map of eastern Nepal.

Gansser, A., 1964, Geology of the Himalayas. London, Intersc. Pub., John Wiley and Sons, London, $289 \mathrm{p}$.
Herail, G., Mascle, G. and Delcaillau, B., 1986. Les Siwaliks de l'Himalaya du Nepal: un example d'evolution geodynamique d'accretion intracontinental. Sciences de la Terre, Nancy, v. 47, pp. 155-182.

Ilic, J. ,1991, CSIRO Atlas of Hardwoods. Craford House Press, Australia.

Jayaveera Don, M.A., 1967, The genus Duabanga. J. Arnold Arb., v. 48, pp. 89-100.

Kramer, K., 1974. Die Tertiaren Holzer Sudost-Asiens (Unter Auschluss der Dipterocarpaceae). Palaeontographica, v. 144, pp. 45-181.

Metcalfe, C.R. and Chalk, L., 1950, Anatomy of Dicotyledons. v. $1 \& 2$, Oxford.

Pearson, R.S. and Brown, H.P., 1932, Commercial timber of India. v. 1 \& 2, Calcutta.

Prakash, U. and Awasthi, N., 1970, Fossils woods from the Tertiary of eastern India I. Palaeobotanist, v. $18(1)$, pp. $32-44$.

Tokuoka, T, Takayasu, K. Youshida, M. and Hisatome, K. 1986, The Churia (Siwaliks) Group of the Arun Khola area, west central Nepal. Mem. Faculty of Science, Shimane University, v. 20, pp. 135-210.

West, R.M. and Munthe, J. 1981, Cenozoic vertebrate palaeontology and stratigraphy of Nepal. Himalayan Geology, v. 11, pp. 18-27.

Willis, J.C. 1973, A dictionary of the flowering plants and ferns. Cambridge. 